\title{
Effect of Secondary and Micronutrients on Growth Attributes, Yield and soil Enzyme Activity of Elephant Foot Yam - A Review
}

\author{
Biswanath Sahoo $^{1 *}$, M. Nedunchezhiyan ${ }^{2}$, P. Acharyya ${ }^{3}$, R. Munshi ${ }^{3}$, \\ S. Tripathy ${ }^{4}$, D. Sahu ${ }^{5}$, Kumari Sunita ${ }^{6}$ and Madhuri Toppo ${ }^{7}$ \\ ${ }^{1}$ Krishi Vigyan Kendra (OUAT), Ranital, Bhadrak, Odisha-756111, India \\ ${ }^{2}$ Regional Centre of ICAR-Central Tuber Crops Research Institute, \\ Bhubaneswar, Odisha-751019, India \\ ${ }^{3}$ Department of Horticulture, University of Calcutta, Kolkata, West Bengal- 700019, India \\ ${ }^{4}$ Department of Agronomy, ${ }^{5}$ Department of Plant Breeding and Genetics, OUAT, \\ Bhubaneswar, Odisha-751003, India \\ ${ }^{6}$ Krishi Vigyan Kendra (OUAT), Madhopur, West Champaran-845454, India \\ ${ }^{7}$ Krishi Vigyan Kendra (OUAT), Jharsuguda, Odisha- 768202, India \\ *Corresponding author
}

Keywords

Nitrogen $(\mathrm{N})$,

Phosphorus (P),

Potassium (K),

Magnesium (Mg),

Zinc (Zn), Boron

(B)

Article Info

Accepted:

10 November 2019

Available Online:

10 December 2019
Rice is the major crop cultivated during kharif in eastern region of India, particularly in Odisha. Inconsistent and erratic behaviour of monsoon, high input costs and low market price at farm gate for rice is becoming unremunerative at times. Crop diversification with high potential crops seems to be a viable solution for the above situations. Elephant foot yam is an important food crop with a variety of alternative uses, has not been tried much in this region. With vast production potential and wide agro-climatic adaptability, if elephant foot yam can fit into the cropping systems of this region, it becomes most suitable answer to the bereaved farmers. However, elephant foot yam exhaust lot of nutrients from the soil owing to its high yield. Alfisols, most predominant in eastern region of India, particularly Odisha is deficient in major nutrients i.e., nitrogen $(\mathrm{N})$, phosphorus $(\mathrm{P})$ and potassium $(\mathrm{K})$ along with minor nutrients especially magnesium $(\mathrm{Mg})$, zinc $(\mathrm{Zn})$, and boron (B). Hence, optimization of site specific nutrient requirement is to be worked out to harness the maximum yield without harming soil health. The work done on these aspects in elephant foot yam and other related tuber crops have been reviewed and discussed below. 


\section{Introduction}

Rice is the major crop cultivated during kharif in eastern region of India, particularly in Odisha. Inconsistent and erratic behaviour of monsoon, high input costs and low market price at farm gate for rice is becoming unremunerative at times. Crop diversification with high potential crops seems to be a viable solution for the above situations. Tuber crops play in the multifaceted needs of more than 500 million people mostly in South and South East Asia, West Africa and the Pacific Ocean Islands contributing to their food, nutritional, social and economic security. The major tropical tuber crops include cassava (Manihot esculenta Crantz.), sweet potato [Ipomoea batatas (L.) Lam.], yams (Dioscorea spp.), aroids like elephant foot yam [Amorphophallus paeoniifolius (Dennst.) Nicolson], taro [Colocasia esculenta (L.) Schott.] and tannia [Xanthosoma sagittifolium (L.) Schott.]. Elephant foot yam is an important food crop with a variety of alternative uses, has not been tried much in this region. With vast production potential and wide agro-climatic adaptability, if elephant foot yam can fit into the cropping systems of this region, it becomes most suitable answer to the bereaved farmers. However, elephant foot yam exhaust lot of nutrients from the soil owing to its high yield. Alfisols, most predominant in eastern region of India, particularly Odisha is deficient in major nutrients i.e., nitrogen $(\mathrm{N})$, phosphorus $(\mathrm{P})$ and potassium $(\mathrm{K})$ along with minor nutrients especially magnesium $(\mathrm{Mg})$, zinc $(\mathrm{Zn})$, and boron (B). Hence, optimization of site specific nutrient requirement is to be worked out to harness the maximum yield.

Soil health is imperative to obtain high yield and quality in tuber crops. Both the chemical and physical condition of the soil can be changed to benefit the tuber production in tropical tuber crops. Judicious application of fertilizers and manures plays a pivotal role in the production technology of tropical tuber crops. The manures used to supplement organic matter to the soil, so that through decay, it furnish more or less continuous supply of nutrients to the crops and improve the soil condition for better tuber bulking. They supply practically all the elements of fertility which crop require, though not in adequate proportion. The application of fertilizers restores or increases the amount of deficient nutrients. They are applied mainly to increase the supply of the essential nutrients, e.g., N, P and $\mathrm{K}$. The nitrogenous fertilizer promotes the vegetative growth of the crop by imparting a healthy green colour to the leaves and it also controls the efficient utilization of $\mathrm{P}$ and $\mathrm{K}$. The phosphatic fertilizer influences the vigour of plants and improves its quality. The role of K may be associated with starch synthesis leading to promotion of tuber growth and accelerated translocation of photosynthates from source to sink.

\section{Effects of secondary and micro (Mg, Zn and B) nutrients}

The absorption and utilization of $\mathrm{Mg}$ increased with age of the crop. However, Mg utilization was higher during tuber bulking stage (Kabeerathumma et al., 1987). As regards to the nutrient content in the plant parts during different growth stages, leaves had the highest concentration of $\mathrm{Mg}$ during all growth stages. The Mg content in the leaf showed a slight decrease at 5 MAP and then increased with maturity. But in the pseudostem, Mg content increased with age of the crop. The root and tuber accounted for higher $\mathrm{Mg}$ at early growth stage which subsequently decreased with maturity.

Zinc is regarded as the third most important limiting nutrient element in crop production after N and P (Gupta, 1995). It was further reported that, $\mathrm{Zn}$ was essential for several 
enzyme systems and its deficiency retarded photosynthesis and $\mathrm{N}$ metabolism in plants.

The uptake of $\mathrm{Zn}$ was meagre in the range of $490 \mathrm{~g} \mathrm{ha}^{-1}$. The depletion of these nutrients from the soil through corm was as $81-82 \% \mathrm{Zn}$ in the different plant parts. The $\mathrm{Zn}$ content in the different plant parts decreased with maturity (Kabeerathumma et al., 1987). Sweet potato responds favourably to the application of $\mathrm{Zn}$. Appreciable increase in sweet potato yield by basal as well as foliar application of Zn was reported by George and Mitra (1996) in the trials conducted at Kharagpur in West Bengal.

Boron is one of the essential micronutrients required for the normal growth and development of plants. Boron is needed for the development and differentiation of tissues particularly growing tips, phloem and xylem (Sakal and Singh, 1995). It also plays an important role in sugar translocation. A combined application of ethrel (500 ppm) as vine dip and soil application of $\mathrm{K}_{2} \mathrm{O} @ 90-120 \mathrm{~kg} \mathrm{ha}^{-1}$ along with foliar application of boric acid $700 \mathrm{~g} \mathrm{ha}^{-1}$ significantly increased the yield and quality of sweet potato tubers in Tripura.

Efkar et al., (1995) studied the response of potato (cv. Desire) to the application of $\mathrm{B}$ fertilizer in Pakistan using 4 levels of B $(0,1$, 1.5 and $\left.2 \mathrm{~kg} \mathrm{ha}^{-1}\right)$. The crop also received a basal dressing of NPK fertilizers and FYM $(5 \mathrm{t}$ $\left.\mathrm{ha}^{-1}\right)$. Application of $2 \mathrm{~kg} \mathrm{~B} \mathrm{ha}{ }^{-1}$ gave the highest tuber yield of $10.9 \mathrm{t} \mathrm{ha}^{-1}$ compared with the control yield of $7.9 \mathrm{t} \mathrm{ha}^{-1}$.

Application of borax @ $10 \mathrm{~kg} \mathrm{ha}^{-1}$ as basal dressing or foliar spray $(0.2 \%)$ of boric acid has been recommended for overcoming the deficiency (Sakal and Singh, 1995).

Byju et al., (2007) determined the B requirement of sweet potato based on B uptake as $1.5 \mathrm{~kg} \mathrm{ha}^{-1}$ borax.

\section{Effects of macro and micro nutrients}

Sarkar et al., (1996) reported the highest tuber yield (28.72 $\left.\mathrm{t} \mathrm{ha}^{-1}\right)$ due to combined effect of $150 \mathrm{~kg} \mathrm{~N}+60 \mathrm{~kg} \mathrm{P}+120 \mathrm{~kg} \mathrm{~K}+20 \mathrm{~kg} \mathrm{~S}$ $+20 \mathrm{~kg} \mathrm{Zn}+2 \mathrm{~kg} \mathrm{~B}+15 \mathrm{~kg} \mathrm{Mg}+5 \mathrm{t}$ cow dung $\mathrm{ha}^{-1}$.

Parmar et al., (2007) reported that tuber yield and profit increased by 34.1 and $31.5 \%$, respectively, with the combined use of fertilizers (N: P: K at 100:75:60 kg ha ${ }^{-1}$ and Fe: Mn: Zn: Cu: B: Mo at 10: 25: 25: 25: 10:1 $\mathrm{kg} \mathrm{ha}^{-1}$ ) and organic manure as compared to farmer's practice.

Arias et al., (2010) carried out an experiment in the town of Pernia, Vargas county in Tachira State, to evaluate the response of potato (variety Granola) to the application of 5 treatments with chemical fertilizers (test without fertilizer; NPK, NPK $+\mathrm{Mg}$, $\mathrm{NPK}+\mathrm{Mg}+\mathrm{B}$ and $\mathrm{NPK}+\mathrm{B})$ and 3 levels of organic fertilizer $\left(0,5\right.$ and $10 \mathrm{tha}^{-1}$ of poultry manure). The results showed that the greatest yield was found with the application of $\mathrm{NPK}+\mathrm{Mg}$ (38.39 $\left.\mathrm{t} \mathrm{ha} \mathrm{ha}^{-1}\right)$, followed by the treatment of NPK+B $\left(35.90 \mathrm{tha}^{-1}\right)$ and $5 \mathrm{t} \mathrm{ha}^{-1}$ of poultry manure $(\mathrm{P}<=0.01)$.

\section{Effects of macro and micro nutrients on tuber quality}

The impact of macro and micronutrients on the quality has not been explored much. Dry matter content in corm was found to be unaffected by different fertility levels which ranged from 20.7 to $23.6 \%$ and starch content from 16.9 to $17.5 \%$ under different levels. It was also observed that as the level of potash increased, the starch content of corms increased, while the oxalic acid content in the corms decreased (Anon, 1981).

Mukhopadhyay and Sen (1986) reported that quality of corms improved with increasing levels of both $\mathrm{N}$ and $\mathrm{K}$. Patel and Mehta 
(1987) reported an increase in $\mathrm{P}, \mathrm{K}$ and silica content in corms with FYM application, but had no effect on starch and $\mathrm{N}$ contents. Further, application of $\mathrm{N}$ increased the $\mathrm{N}, \mathrm{P}, \mathrm{K}$, starch and silica contents of the corms.

Some researchers reported that oxalate content differed for any kind of plant species depending on age, physiology, environment, and genetic makeup (Libert and Franceschi, 1987).

Palaniswamy et al., (2002, 2004) explained that oxalic acid was influenced by nitrogen (soil mineral) and the age of leaves in hydroponic vegetable plant Portulaca oleraceae L.

Taheri (2011) conducted a field experiment to investigate the effect of compost and manure with phosphorus and zinc on potato (Solanum tuberosum L.) quality. Tuber dry matter was significantly affected by zinc and phosphorus interaction, so that the maximum dry matter was obtained by using $225 \mathrm{~kg} \mathrm{ha}^{-1}$ TSP and 50 $\mathrm{kg} \mathrm{ha}^{-1} \mathrm{ZnSO}_{4}$.

\section{Enzymatic studies in relation to nutrients regime}

Enzymes in soil are similar to enzymes in other systems, in that their reaction rates are markedly dependent on $\mathrm{pH}$, ionic strength, temperature and the presence or absence of inhibitors (Burns, 1978 and Tabatabai, 1982). Enzymes synthesized by plants, added to soil as plant residue, may remain active. Phosphatase activity in soil has been observed to be associated with intact cell wall fragments and with amorphous organic material (Ladd, 1978).

Enzyme activity is considerably greater in the rhizosphere of plants than in bulk soil, and this increased activity is due to either a specific flora or on the plant root or both (Skujins, 1967).

Phosphatase activity can significantly increase after the application of organic manures (Guan, 1989). Acid and alkaline phosphatase enzymes are involved in the solubilization of macromolecular organic phosphates in soils (Panara et al., 1990).

The application of FYM or chemical fertilizer effectuated higher levels of enzyme activity as compared to control (Kirchner et al., 1993; Emmerling et al., 2000).

Incorporation of organic manures influences soil enzymatic activity either because of the composition of the added materials themselves or because they increase microbial activity of the soil (Goyal et al., 1993).

Increase in phosphatase and urease activities coincided mainly with increase in bacterial biomass and with the rapid immobilization of labeled $\mathrm{N}$. The effect of long term cattle manure application on soil phosphorous levels and phosphatase activities was studied by Parham et al., (2002). An assay on the rates of activity of these enzymes may be used to ascertain biological demand for phosphates in the soil (Yenigun and Guvenilir, 2003).

\section{References}

Anonymous, (1981). Annual Report. Central Tuber Crops Research Institute, Trivandrum, Kerala.

Arias, K., (2010). Effect of the fertilization chemical, organic and combined on the yield of variety Granola. Agronomia Trop. Maracay. 60(1): 75-84.

Burns, R.G., (1978). Enzyme activity in soil: Some theoretical and practical considerations. In: Soil Enzymes (Ed.) Bums, R.G., Academic Press, London, pp. 295-340. 
Byju et al., (2007). Sweet potato response to boron application on an alfisols in the sub humid tropical climate of India. Commun. Soil Sci. Pl. Anal. 38: 2347-2356.

Efkar et al., (1995). Potato yield as affected by boron fertilizer mixing with and without farmyard manure. Sarhad J. Agric. 11(6): 725-728.

Emmerling et al., (2000). Functional diversity of soil organisms - a review of recent research activities in Germany. $J$. Plant Nutr. Soil Sci. 165: 408-420.

George, J. and Mitra, B.N., (1996). Effect of application of fly ash and paper factory sludge as source of micronutrients on the performance of sweet potato. In: Tropical Tuber Crops in Food Security and Nutrition (Eds.)

Balagopalan et al., Oxford and IBH Publishing Co. Pvt. Ltd., New Delhi. pp. 338-343.

Goyal et al., (1993). Microbial biomass turnover and enzyme activities following the application of farmyard manure to field soils with and without previous long term applications. Biol. Fertility Soils. 15: 60-64.

Guan, S.Y., (1989). Studies on the factors influencing soil enzyme activities: Effect of organic manures on soil enzyme activities and $\mathrm{N}$ and $\mathrm{P}$ transformations. Acta Pedol. Sinica. 26: 72-78.

Gupta, V.K., (1995). Zinc research and agricultural production. In: Micronutrient research and Agricultural production (Ed.) Tandon, H.L.S., pp. 132-164.

Kabeerathumma et al., (1987). Nutrient uptake and their utilization by Yams, aroides and coleus. Technical Bulletin Series no.10, CTCRI, Thrivanthapuram, Kerala, India, pp. 34.

Kirchner et al., (1993). Soil microbial populations and activities in reduced chemical input agro ecosystems. Soil
Sci. Soc. Am. J. 57: 1289-1295.

Ladd, J.N., (1978). Origin and range of enzymes in soil. In: Soil Enzymes (Ed.) Burns, R.G., Academic Press, London, pp. 51-96.

Libert, B. and Franceschi, V.R., (1987). Oxalate in crop plants. J. Agric. Food Chem. 35: 926-938.

Mukhopadhyay, S.K. and Sen, H., (1986). Effect of nitrogen and potassium on yield and quality of elephant foot yam (Amorphophallus campanulatus Blume). J. Root Crops. 12 (2): 103106.

Palaniswamy et al., (2002). Effect of nitrate: ammonium nitrogen ratio on oxalate levels of purslane. In: Trends in New Crops and New Uses (Eds.) Janick, J. and Whipkey, A., ASHS Press. Alexandria, VA.

Palaniswamy et al., (2004). Oxalic acid concentrations in purslane (Portulaca oleraceae L.) are altered by the stage of harvest and the nitrate to ammonium ratios in hydroponics. Scientia Hort. 102: 267-275.

Panara et al., (1990). Multiple forms of plant acid phosphatase: Purification and some characteristics of major cytoplasmic iso-enzyme. Biochem. Biophys. Acta. 1037: 73-80.

Parham et al., (2002). Long-term cattle manure application in soil. I. Effect on soil phosphorus levels, microbial biomass $\mathrm{C}$, and dehydrogenase and phosphatase activities. Biol. Fertil. Soils. 35: 328-337.

Parmar et al., (2007). Increasing potato productivity and profitability with an integrated production system. Intern. J. Veg. Sci. 13(4): 33-43.

Patel, B.M. and Mehta, H.M., (1987). Effect of farm yard manure, spacing and nitrogen application on chemical constituents of elephant foot yam (Amorphophallus campanulatus). 
Gujarat Agric. Univ. Res. J. 13(1): 4647.

Sakal, R. and Singh, A.P., (1995). Boron research and agricultural production. In: Micronutrients Research and Agricultural Production. Tandon, H.L.S (Ed.). IBH \& Oxford Publishing Company, New Delhi.

Sarkar et al., (1996). Effect of fertilizers alone and in combination with cow dung on the growth and yield of potato. Bangladesh J. Agril. Sci. 21 (1): 275282.

Skujins, J., (1967). Enzymes in soil. In: Soil Biochemistry (Eds.) McLaren, A. D. and Peterson, G. H., Vol. 1., Marcel
Dekker, New York, pp. 371-414.

Tabatabai, M.A., (1982). Soil enzyme. In: Methods of Soil Analysis (Ed.) Page, A.L., Part II, American Society of Agronomy, Madison, Wisconsin, pp. 903-948.

Taheri et al., (2011). Effect of organic manure with phosphorus and zinc on yield of seed potato. Australian J. Basic App. Sci. 5 (8): 775-780.

Yenigun, B. and Guvenilir, Y., (2003). Partial purification and kinetic characterization of acid phosphatase from garlic seedlings. App. Biochem. Biotech. 105: 677-687.

\section{How to cite this article:}

Biswanath Sahoo, M. Nedunchezhiyan, P. Acharyya, R. Munshi, S. Tripathy, D. Sahu, Kumari Sunita and Madhuri Toppo. 2019. Effect of Secondary and Micronutrients on Growth Attributes, Yield and soil Enzyme Activity of Elephant Foot Yam - A Review. Int.J.Curr.Microbiol.App.Sci. 8(12): 950-955. doi: https://doi.org/10.20546/ijcmas.2019.812.121 